\title{
A Review on the Biotechnological Applications of the Operational Group Bacillus amyloliquefaciens
}

\author{
Mohamad Syazwan Ngalimat ${ }^{1}$ (D), Radin Shafierul Radin Yahaya ${ }^{1}$, Mohamad Malik Al-adil Baharudin ${ }^{1}$, \\ Syafiqah Mohd. Yaminudin ${ }^{2}$, Murni Karim ${ }^{2,3}$ (D), Siti Aqlima Ahmad 4 (D) and Suriana Sabri 1,5,*(D) \\ 1 Enzyme and Microbial Technology Research Center, Faculty of Biotechnology and Biomolecular Sciences, \\ Universiti Putra Malaysia, Serdang 43400, Selangor, Malaysia; syazwanngalimat@gmail.com (M.S.N.); \\ radinshafierul@yahoo.com (R.S.R.Y.); malikaladilbaharudin@gmail.com (M.M.A.-a.B.) \\ 2 Department of Aquaculture, Faculty of Agriculture, Universiti Putra Malaysia, \\ Serdang 43400, Selangor, Malaysia; nsmy211195@gmail.com (S.M.Y.); murnimarlina@upm.edu.my (M.K.) \\ 3 Laboratory of Sustainable Aquaculture, International Institute of Aquaculture and Aquatic Sciences, \\ Universiti Putra Malaysia, Port Dickson 71050, Negeri Sembilan, Malaysia \\ 4 Department of Biochemistry, Faculty of Biotechnology and Biomolecular Sciences, Universiti Putra Malaysia, \\ Serdang 43400, Selangor, Malaysia; aqlima@upm.edu.my \\ 5 Department of Microbiology, Faculty of Biotechnology and Biomolecular Sciences, Universiti Putra Malaysia, \\ Serdang 43400, Selangor, Malaysia \\ * Correspondence: suriana@upm.edu.my; Tel.: +603-97698298
}

check for updates

Citation: Ngalimat, M.S.; Yahaya, R.S.R.; Baharudin, M.M.A.-a.; Yaminudin, S.M..; Karim, M.; Ahmad, S.A.; Sabri, S. A Review on the Biotechnological Applications of the Operational Group Bacillus amyloliquefaciens. Microorganisms 2021, 9, 614. https://doi.org/10.3390/ microorganisms 9030614

Academic Editor: Stefan Junne

Received: 22 January 2021

Accepted: 26 February 2021

Published: 17 March 2021

Publisher's Note: MDPI stays neutral with regard to jurisdictional claims in published maps and institutional affiliations.

Copyright: (c) 2021 by the authors. Licensee MDPI, Basel, Switzerland. This article is an open access article distributed under the terms and conditions of the Creative Commons Attribution (CC BY) license (https:/ / creativecommons.org/licenses/by/ $4.0 /)$.

\begin{abstract}
Bacteria under the operational group Bacillus amyloliquefaciens (OGBa) are all Gram-positive, endospore-forming, and rod-shaped. Taxonomically, the OGBa belongs to the Bacillus subtilis species complex, family Bacillaceae, class Bacilli, and phylum Firmicutes. To date, the OGBa comprises four bacterial species: Bacillus amyloliquefaciens, Bacillus siamensis, Bacillus velezensis and Bacillus nakamurai. They are widely distributed in various niches including soil, plants, food, and water. A resurgence in genome mining has caused an increased focus on the biotechnological applications of bacterial species belonging to the OGBa. The members of OGBa are known as plant growthpromoting bacteria (PGPB) due to their abilities to fix nitrogen, solubilize phosphate, and produce siderophore and phytohormones, as well as antimicrobial compounds. Moreover, they are also reported to produce various enzymes including $\alpha$-amylase, protease, lipase, cellulase, xylanase, pectinase, aminotransferase, barnase, peroxidase, and laccase. Antimicrobial compounds that able to inhibit the growth of pathogens including non-ribosomal peptides and polyketides are also produced by these bacteria. Within the OGBa, various $B$. velezensis strains are promising for use as probiotics for animals and fishes. Genome mining has revealed the potential applications of members of OGBa for removing organophosphorus (OPs) pesticides. Thus, this review focused on the applicability of members of OGBa as plant growth promoters, biocontrol agents, probiotics, bioremediation agents, as well as producers of commercial enzymes and antibiotics. Here, the bioformulations and commercial products available based on these bacteria are also highlighted. This review will better facilitate understandings of members of OGBa and their biotechnological applications.
\end{abstract}

Keywords: plant growth-promoting bacteria; biocontrol agent; enzymes; antimicrobial compounds; probiotics; bioremediation; Bacillus amyloliquefaciens; Bacillus velezensis; Bacillus siamensis; Bacillus nakamurai

\section{Introduction}

In 1943, a Japanese scientist, Juichiro Fukumoto, first isolated Bacillus amyloliquefaciens from the soil. The species is named after its unique character because it produced (faciens) a liquefying (lique) $\alpha$-amylase (amylo) [1,2]. Later, B. amyloliquefaciens was combined with the closely related Bacillus subtilis and Bacillus licheniformis into the B. subtilis species complex, based on phylogenetic and phenetic evidence [3]. From the B. subtilis species complex, it can be further sub-grouped into the operational group $B$. amyloliquefaciens (OGBa) that 
comprises four bacterial species; the soil-borne B. amyloliquefaciens, the plant-associated Bacillus siamensis and Bacillus velezensis, and a black-pigment-producing strain Bacillus nakamurai [4].

Previously, several bacterial species of the OGBa, namely B. amyloliquefaciens subsp. plantarum, Bacillus methylotrophicus and Bacillus oryzicola, were reclassified as strains of $B$. velezensis [5]. Genome-based and gene-derived phylogenetic analyses revealed that $B$. velezensis belongs to a conspecific group consisting of $B$. velezensis, $B$. amyloliquefaciens subsp. plantarum FZB42 (reclassified as B. velezensis FZB42) and B. methylotrophicus. However, $B$. velezensis is distinct from the closely related species of $B$. amyloliquefaciens and B. siamensis [4]. To date, a plethora of bacterial whole-genome sequences (WGS) from members of OGBa have been deposited into the National Center Biological Information (NCBI) database (Table S1). As confirmed taxonomically in 2019, 223 genomes belonged to $B$. velezensis, 19 belonged to B. amyloliquefaciens, 10 belonged to $B$. siamensis and 2 belonged to $B$. nakamurai [6].

The members of OGBa are found in various niches including soil, plants, food, animal faeces and aquatic environments [4]. Currently, genome mining has revealed their applicability as plant growth-promoters, biocontrol agents, probiotics, bioremediation agents as well as producers of commercial enzymes and antibiotics [7,8]. Therefore, knowledge of the biology of the OGBa is imperative to understanding the special qualities of the group. This review focused on the biotechnological applications of the bacterial strains belonging to the OGBa.

\section{An Overview of the OGBa}

\subsection{Identification and Characterization}

Bacterial species from the OGBa are all Gram-positive bacteria and motile by peritrichous flagella. They are endospore-forming bacteria from the B. subtilis species complex. For many years, the speciation of OGBa within the $B$. subtilis species complex has been uncertain, often leading to erroneous and variable results. They are difficult to distinguish using classical taxonomy parameters: morphological and physiological characteristics, cell wall compositions, $16 \mathrm{~S}$ ribosomal RNA sequence, guanine-cytosine $(\mathrm{G}+\mathrm{C})$ content, fatty acid methyl esters (FAME) and DNA-DNA hybridization (DDH) [9]. Therefore, the taxonomic status of the bacterial species belonging to the OGBa is constantly causing confusion to researchers, especially for non-professional taxonomy researchers.

It is worth mentioning that some studies have used protein-coding genes in order to further ascertain the degree of relatedness of the OGBa within the $B$. subtilis species complex $[10,11]$. The highly conserved DNA gyrase subunit B $(g y r B)$, signal transduction histidine kinase CheA (che $A$ ) and RNA polymerase $\beta$-subunit (rpoB) were used for the study of speciation within the $B$. subtilis species complex before the advent of multilocus sequence analysis (MLSA) [11-13]. The taxonomical status of the members of OGBa has been solved by genome-based [4] and gene-derived [14] phylogeny analyses. The OGBa comprised four species: (i) B. amyloliquefaciens; (ii) B. siamensis; (iii) B. velenzensis; and (iv) $B$. nakamurai, as confirmed by cladistic analysis (Figure 1; Table 1). 


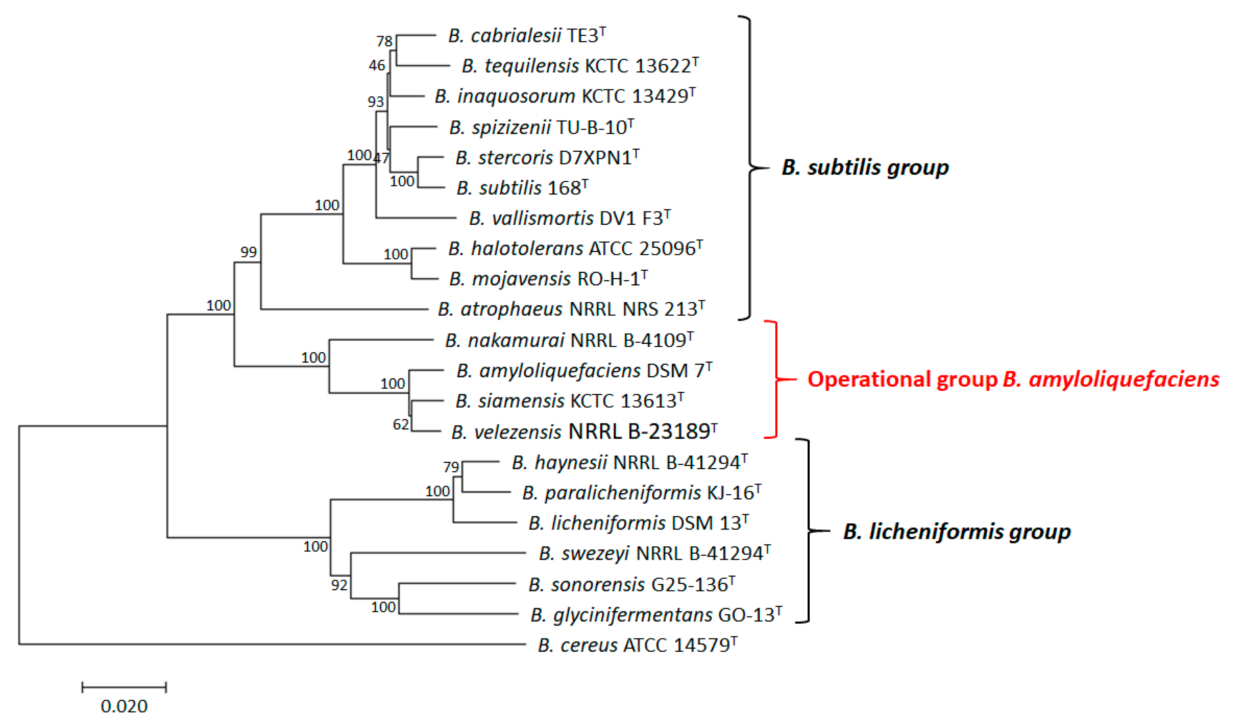

Figure 1. Neighbor-joining phylogenetic tree based on complete rpoB nucleotide sequences of bacterial species under the B. subtilis species complex. Evolutionary analyses were conducted using the MEGAX software [15]. The optimal tree with the sum of branch length $=0.66533958$ is shown The evolutionary distances were computed using the $p$-distance method. Bootstrap values, based on 1000 repetitions, are indicated at the branch points. The analysis involved 19 nucleotide sequences. There were 3534 positions in the final dataset. Bar, 0.02 substitutions per nucleotide position. Bacillus cereus ATTC $14579^{\mathrm{T}}$ was used as the outgroup.

Table 1. Characterizations of bacterial species under the operational group Bacillus amyloliquefaciens.

\begin{tabular}{|c|c|c|c|c|c|}
\hline \multicolumn{2}{|c|}{ Characterization } & B. amyloliquefaciens & B. siamensis & B. velezensis & B. nakamurai \\
\hline \multicolumn{2}{|c|}{ Type Strain } & $\begin{array}{c}\operatorname{DSM} 7^{\mathrm{T}} / \operatorname{ATCC~} 23350^{\mathrm{T}} / \\
\mathrm{F}^{\mathrm{T}}\end{array}$ & $\begin{array}{c}\text { KCTC } 13613^{\mathrm{T}} / \text { PD-A10 } \\
\text { / BCC } 22614^{\mathrm{T}}\end{array}$ & 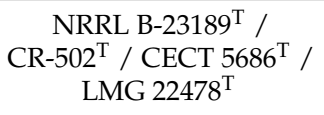 & $\begin{array}{l}\text { NRRL B- } 41091^{\mathrm{T}} / \\
{\text { CCUG } 68786^{\mathrm{T}}}^{\text {C }}\end{array}$ \\
\hline \multicolumn{2}{|c|}{ Isolation Source } & $\begin{array}{c}\text { Soil and industrial } \\
\alpha \text {-amylase fermentations }\end{array}$ & $\begin{array}{c}\text { Salted crab (poo-khem) in } \\
\text { Thailand }\end{array}$ & $\begin{array}{l}\text { Brackish water sample } \\
\text { from the river Velez at } \\
\text { Torredelmar in Ma'laga, } \\
\text { southern Spain }\end{array}$ & $\begin{array}{l}\text { Soil in Tierra del } \\
\text { Fuego, Argentina }\end{array}$ \\
\hline \multicolumn{2}{|c|}{ Size } & $0.7-0.9 \times 1.8-3.0 \mu \mathrm{m}$ & $0.3-0.6 \times 1.5-3.5 \mu \mathrm{m}$ & $0.5 \times 1.5-3.5 \mu \mathrm{m}$ & $\begin{array}{c}0.74-0.93 \times 1.39-2.04 \\
\mu \mathrm{m}\end{array}$ \\
\hline \multicolumn{2}{|c|}{ Endospore } & $\begin{array}{l}\text { Oval spores are central or } \\
\text { paracentral in unswollen } \\
\text { sporangia }\end{array}$ & $\begin{array}{l}\text { Ellipsoidal spores are } \\
\text { central or sub-terminal } \\
\text { positions in swollen } \\
\text { sporangia }\end{array}$ & $\begin{array}{l}\text { Ellipsoidal spores are } \\
\text { paracentral or } \\
\text { sub-terminal positions in } \\
\text { unswollen sporangia }\end{array}$ & $\begin{array}{c}\text { Ellipsoidal spores are } \\
\text { central in unswollen } \\
\text { sporangia }\end{array}$ \\
\hline \multicolumn{2}{|c|}{ G + C Content (mol \%) } & 44.6 & 41.4 & $46.1-46.4$ & 43.8 \\
\hline \multicolumn{2}{|c|}{ Growth Temperature } & $\begin{array}{l}\text { Optimal growth } \\
\text { temperature is } 30-40{ }^{\circ} \mathrm{C} \text {. } \\
\text { No growth occurs below } \\
15^{\circ} \mathrm{C} \text { or above } 50{ }^{\circ} \mathrm{C} \text {. }\end{array}$ & $\begin{array}{l}\text { Optimal growth } \\
\text { temperature is } 37^{\circ} \mathrm{C} \text {. } \\
\text { Growth occurs at } 4{ }^{\circ} \mathrm{C} \\
\text { and } 55^{\circ} \mathrm{C} .\end{array}$ & $\begin{array}{l}\text { Grow within } \\
\text { the temperature range of } \\
15-45^{\circ} \mathrm{C}\end{array}$ & $\begin{array}{l}\text { Grow within } \\
\text { the temperature } \\
\text { range of } 17-50{ }^{\circ} \mathrm{C} \text {, } \\
\text { with an optimum of } \\
37^{\circ} \mathrm{C}\end{array}$ \\
\hline \multicolumn{2}{|c|}{$\mathrm{NaCl}$ Resistance $(w / v)$} & $\begin{array}{l}\text { Growth occurs with } \\
0-10 \% \mathrm{NaCl}\end{array}$ & $\begin{array}{l}\text { Growth occurs with } \\
0-14 \% \mathrm{NaCl}\end{array}$ & $\begin{array}{l}\text { Growth occurs with } \\
0-12 \% \mathrm{NaCl}\end{array}$ & $\begin{array}{l}\text { Growth occurs with } \\
0-9 \% \mathrm{NaCl}\end{array}$ \\
\hline \multirow{2}{*}{$\begin{array}{l}\text { Substrate } \\
\text { Utilization }\end{array}$} & Tyrosine & - & - & - & + \\
\hline & Citrate & + & - & - & + \\
\hline \multirow{2}{*}{$\begin{array}{l}\text { Fermentation } \\
\qquad \text { (acid) }\end{array}$} & Lactose & + & + & + & - \\
\hline & Trehalose & + & - & + & + \\
\hline \multicolumn{2}{|c|}{ Reference } & [1] & [16] & [17] & [18] \\
\hline
\end{tabular}

Note: All the bacterial species are able to metabolize casein, gelatin, starch, fructose, cellobiose, glucose, glycerol, maltose, mannitol, raffinose, salicin and sucrose. Symbol: +, positive result; -, negative result. 


\subsection{Ecology, Isolation and Cultivation}

The ability to produce endospores when facing harsh conditions allowed the members of the operational group to survive in various niches including soil, animal faeces, plants, food, bee products, drugs, air, and the aquatic environments (Table S1). Evidently, the members of OGBa had been directly isolated from rare dormant volcanic soils [19], mango orchards [20] and animal faeces [21,22]. They had also been isolated from plant parts including fruits (such as lemons [23] and apples [24]), roots (such as Peruvian ground cherry [25] and peanut roots [26]) and leaves (such as lucerne [27] and camphor leaves [28]).

Moreover, traditional fermented foods including bibimbap [29], douchi [30], and doenjang [31] were reported as the sources of isolation of bacteria from this operational group. They also were isolated from bee products [32-34], heroin [35], and air [36]. In other related studies, bacteria of this operational group have been isolated from water [37], seawater [38] and sea sediment [39]. Chicken [40] and fish intestines [41] were also reported as the sources of origin for members of this operational group.

Generally, the members of OGBa are cultivated routinely in Luria-Bertani (LB) medium at $30-37^{\circ} \mathrm{C}$ aerobically $[11,16,17]$. Some members of OGBa such as B. nakamurai grew well on nutrient agar (NA), trypticase soy agar (TSA), Reasoner's 2A agar (R2A) and tryptone glucose yeast extract agar (TGY) at $30^{\circ} \mathrm{C}$ for two days [18]. Moreover, B. velezensis and $B$. siamensis were also reported to grow well on TSA at $37^{\circ} \mathrm{C}$ and $32^{\circ} \mathrm{C}$, respectively [16,17].

\subsection{Genome and Its Arrangement}

In 2019, 254 bacterial strain genomes which had been deposited in the NCBI database were reported as belonging to the OGBa [6]. Some of the examined strains were found to contain plasmids (Table S1). Most of the reported strains had only one plasmid, except for B. velezensis 157, B. velezensis DKU_NT_04, and B. velezensis NJAU-Z9 (all contained two plasmids), and B. velezensis LB002 (which contained three plasmids). Interestingly, some studies have focused on the functionality of the genes carried by the plasmid. For instance, the B. velezensis S499 plasmid, pS499, was reported as containing a rap-phr cassette. This cassette encoded for the regulator aspartate phosphatase (rap) and the Rap regulatory peptide $(p h r)$ with a role in governing protease secretion, growth and motility, biofilm formation and production of surfactin [42]. Meanwhile, B. amyloliquefaciens LL3 plasmid, $\mathrm{pMC1}$, has a $6.8 \mathrm{kbp}$ plasmid that includes a rap which is not homologous to the pS499 [42]. The hypothetical rap and the origin of replication of the $\mathrm{pMC1}$ plasmid were cloned into the pKSV7, vector which brought about the production of plasmid-cured strains. The plasmidcured strains have increases in glutamate-independent poly- $\gamma$-glutamic acid production by $6 \%$ as compared to the B. amyloliquefaciens LL3 [43].

Genome analysis allowed for further biological studies on the members of OGBa. The genomic and metabolic features of the members of the group were similar; however, species-specific features including secondary metabolite biosynthesis-related and energy metabolism-related genes were also identified $[4,44]$. Secondary metabolite biosynthesisrelated genes are enriched in $B$. velezensis, whereas energy metabolism-related genes are enriched in B. amyloliquefaciens. In the core-genome, B. velezensis harbors more genes involved in the biosynthesis of antimicrobial compounds as well as genes involved in $D^{-g a l a c t u r o n a t e}$ and $\mathrm{D}_{\mathrm{D}}$-fructuronate metabolisms compared to $B$. amyloliquefaciens and $B$. siamensis. Moreover, a xanthine oxidase gene cluster that is involved in metabolizing xanthine and uric acid to glycine and oxalureate was found in the core-genome of all the members of the group. Pan-genome analysis revealed the abilities of members of OGBa to metabolize diverse carbon sources aerobically or anaerobically. Their abilities to produce various metabolites such as lactate, ethanol, xylitol, diacetyl, acetoin, and 2,3-butanediol were also identified [44]. In addition, genome analysis suggested that the regions of genomic plasticity controlled the function and structure of the genome and governed the adaptations to different niches [45]. Genome analysis also enabled the prediction of uncharacterized gene clusters and assessed the capabilities of members of OGBa to produce antimicrobial compounds [6]. 


\section{The Importance and Applications of the OGBa}

\subsection{Plant Growth Promoters and Biocontrol Agents in Agriculture}

In the agricultural sector, the biocontrol strategy has received great attention because it provides safe, environmentally friendly, long-lasting, and inexpensive alternatives [46]. The characterizations of the bacterial strains from the OGBa as biocontrol agents were determined based on their abilities to improve plant growth and health [47]. These abilities involve multiple mechanisms including direct (improve plant growth) and indirect (improve plant health) mechanisms (Figure 2). Direct mechanisms involve nitrogen fixation, phosphate solubilization, siderophore production and phytohormone production (e.g., indole-3-acetic acid (IAA) and enzymes such as 1-amyclocyclopropane-1-carboxylate (ACC) deaminase). It has been reported that the co-inoculation of B. velezensis S141 with Bradyrhizobium diazoefficiens USDA110 into soybean resulted in enhanced nodulation and nitrogen fixation efficiency by producing larger nodules [48]. In another related study, the members of OGBa were able to solubilize phosphate, and produce IAA, ACC deaminase and siderophores [49-51].

Meanwhile, the indirect mechanism is mainly due to their biocontrol activities attributed to the production of antimicrobial compounds in response to biotic stress [52]. The members of OGBa produced antimicrobial compounds such as hydrogen cyanide $(\mathrm{HCN})$ and cyclic lipopeptides such as surfactin used to inhibit the growth of pathogenic microbes [53,54]. The interactions of biocontrol agents with plant roots enhance plant resistance against some competing microbes including pathogenic bacteria, fungi and viruses. This phenomenon is termed as induced systemic resistance (ISR) [6,55].

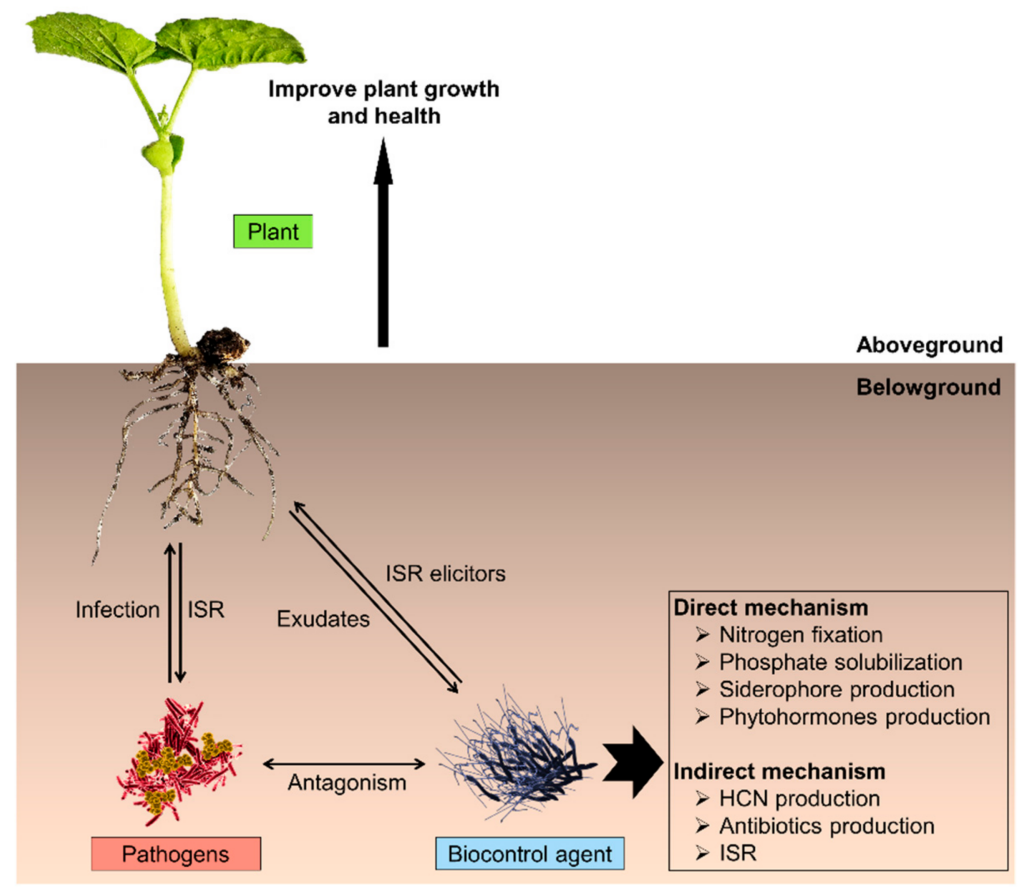

Figure 2. The biological control interactions. The illustration depicts the interactions between biocontrol agents, plant pathogens, and plants. The biocontrol agent colonized the plant root surface and produced antimicrobial compounds such as surfactin. In the plant rhizosphere, antibiosis and nutrient competition interaction suppressed the growth of pathogens. Due to the production of antimicrobial compounds and in the simultaneous presence of pathogens, the induced systemic resistance (ISR) is enhanced. Thus, this mediated the defense response of the plant towards pathogens and consequently improved plant growth and the defense mechanism against pathogens.

The members of OGBa were proven to provide advantages to the agricultural sector by contributing to plant pathogen disease suppression. In plant disease management, the members of OGBa acted as plant growth-promoting bacteria (PGPB) that aid in the devel- 
opment of plants and reduce the proliferation of plant pathogens (Table 2). The secretion of antimicrobial compounds such as surfactin from PGPB was suggested to trigger the pathways of ISR which contributed to the suppressive effect of plant immunity $[56,57]$. Surfactin was determined to act as elicitors of plant immunity and enhance resistance towards further pathogenesis in plants [47]. In the lettuce rhizosphere, increased production of surfactin by B. velezensis FZB42 in the axenic system was suggested to contribute to the disease suppression towards Rhizoctonia solani infection [53]. Similarly, the treatment using B. velezensis FZB42 in tobacco plants was suggested improve ISR and enhance plant height and fresh weight, while lowering the disease severity rating of the tobacco mosaic virus (TMV) [58].

Table 2. Plant pathogen suppression by members of the operational group Bacillus amyloliquefaciens in various plant species.

\begin{tabular}{|c|c|c|c|}
\hline PGPB Strain & Disease and Pathogen & Plant Species & Reference \\
\hline B. siamensis KCТC 13613 & $\begin{array}{c}\text { R. solani } \\
\text { Botrytis cinerea } \\
\text { Micrococcus luteus }\end{array}$ & Arabidopsis thaliana & [59] \\
\hline B. velezensis 83 & Anthracnose disease & $\begin{array}{l}\text { Zea mays } \\
\text { A. thaliana }\end{array}$ & [20] \\
\hline B. velezensis $1 \mathrm{~B}-23$ & Clavibacter michiganensis subsp. michiganensis & Solanum lycopersicum & [60] \\
\hline B. velezensis $\mathrm{B} 25$ & Fusarium verticillioides & Z. mays & [61] \\
\hline B. velezensis BTLK6A & \multirow{2}{*}{ Magnaporthe oryzae Triticum } & \multirow{2}{*}{ Triticum aestivum } & \multirow{2}{*}{ [62] } \\
\hline B. velezensis BTS 4 & & & \\
\hline B. velezensis CC09 & Powdery mildew disease & T. aestivum & [28] \\
\hline B. velezensis CGMCC 11640 & Botryosphaeria dothidea & Carya cathayensis & [63] \\
\hline B. velezensis Co1-6 & $\begin{array}{c}\text { Verticillium dahliae } \\
\text { R. solani } \\
\text { Fusarium culmorum } \\
\text { Ralstonia solanacearum }\end{array}$ & Matricaria chamomilla & [64] \\
\hline B. velezensis GB1 & Valsa mali & Malus domestica & [65] \\
\hline B. velezensis GH1-13 & $\begin{array}{l}\text { Fusarium fujikuroi } \\
\text { R. solani } \\
\text { Xanthmonas oryzae }\end{array}$ & Oryza sativa & [49] \\
\hline B. velezensis GQJK49 & F. solani & Lycium barbarum $\mathrm{L}$. & [66] \\
\hline B. velezensis GYL4 & Anthracnose disease & Cucumis sativus L. cv. Chunsim & [67] \\
\hline B. velezensis $\mathrm{J}-5$ & B. cinerea & S. lycopersicum & [68] \\
\hline B. velezensis JK & M. oryzae & O. sativa & [69] \\
\hline B. velezensis L-1 & Botryosphaeria berengeriana & Pyrus communis & [70] \\
\hline B. velezensis LM2303 & Fusarium graminearum & T. aestivum & [71] \\
\hline B. velezensis M27 & Sclerotinia sclerotiorum & Lactuca sativa $\mathrm{L}$. & [72] \\
\hline B. velezensis NJAU-Z9 & $\begin{array}{l}\text { Fusarium oxysporum f. sp. niveum } \\
\text { Ralstonia solanacearum }\end{array}$ & Capsicum annuum L. & [73] \\
\hline B. velezensis NJN-6 & F. oxysporum f. sp. cubense & Musa sp. & [74] \\
\hline B. velezensis OEE1 & F. solani & Olea europaea L. & [75] \\
\hline B. velezensis $\mathrm{P} 42$ & Bacterial wilt and early blight diseases & S. lycopersicum & [76] \\
\hline B. velezensis PG12 & Apple ring rot disease & Malus domestica & [24] \\
\hline B. velezensis TrigoCor1448 & Fusarium head blight disease & T. aestivum & [77] \\
\hline B. velezensis UCMB5113 & $\begin{array}{c}\text { Alternaria brassicae } \\
\text { B. cinerea } \\
\text { Leptosphaeria maculans } \\
\text { Verticillium longisporum }\end{array}$ & Brassica napus & [78] \\
\hline B. velezensis XK-4-1 & Verticillium wilt disease & Gossypium sp. & [79] \\
\hline B. velezensis ZF2 & Corynespora leaf spot diseases & C. sativus & [80] \\
\hline
\end{tabular}


Bacterial species from the OGBa are used in bioformulations. For instance, the bacterial strain $B$. velezensis FZB42 had been established as a model strain for plant growth promotion and as a biocontrol agent [55]. In 2019, tomato seeds coated with gum arabic as adhesive along with liquid bioformulations containing B. velezensis FZB42 showed great inhibitory effects against Fusarium solani infections under in vitro conditions. Increments in germination percentage and germination rate as compared with the control were also reported [81].

To date, there are a few bioformulations containing bacterial species from the OGBa available on the market (Table 3), such as SERENADE ${ }^{\circledR}$ (Bayer Crop Science, Germany) which contains B. velezensis QST 713 (previously B. subtilis QST 713) and Double Nickel $55^{\mathrm{TM}}$ (Certis Columbia, MD USA) which contains B. velezensis D747 (previously B. amyloliquefaciens D747) [55]. The application of SERENADE ${ }^{\circledR}$ together with Fracture fungicide (CEV, Portugal), which contains BLAD polypeptide, had shown notable success in controlling Botrytis blossom blight disease infection in blueberries [82]. Application of Double Nickel $55^{\mathrm{TM}}$ was found to be effective in controlling white mold in snap beans caused by Sclerotinia sclerotiorum. Double Nickel $55^{\mathrm{TM}}$, a biofungicide, was approved for organic vegetable production by the National Organic Program and Organic Materials Review Institute [83].

Table 3. Some commercial products containing the members of the operational group Bacillus amyloliquefaciens available on the market.

\begin{tabular}{|c|c|c|c|}
\hline Bacterial Strain & Commercial Product & Company & Description \\
\hline \multirow{3}{*}{$\begin{array}{l}\text { B. velezensis QST } 713 \\
\text { (previously B. subtilis QST 713) }\end{array}$} & SERENADE Max & $\begin{array}{c}\text { Bayer Crop Science, previously } \\
\text { AgraQuest }\end{array}$ & $\begin{array}{l}\text { EPA-registered biofungicide. Controls and } \\
\text { suppresses fungal pathogens on foliage } \\
\text { and in the soil }\end{array}$ \\
\hline & SERENADE SOIL ${ }^{\circledR}$ & $\begin{array}{c}\text { Bayer Crop Science, previously } \\
\text { AgraQuest }\end{array}$ & EPA-registered biofungicide for food crops \\
\hline & $\mathrm{CEASE}^{\circledR}$ & $\begin{array}{l}\text { BioWorks, Inc., Victor, New York, } \\
\text { U.S.A. }\end{array}$ & $\begin{array}{l}\text { Aqueous suspension biofungicide for leafy } \\
\text { and fruiting vegetables, herbs and spices, } \\
\text { and ornamentals }\end{array}$ \\
\hline \multirow{3}{*}{$\begin{array}{l}\text { B. velezensis FZB42 } \\
\text { (previously B. amyloliquefaciens } \\
\text { FZB42) }\end{array}$} & RhizoVital $^{\circledR} 42$ & ABiTEP GmbH, Berlin, Germany & $\begin{array}{l}\text { Biofertilizer, plant-growth-promoting } \\
\text { activity, provides protection against } \\
\text { various soil-borne diseases }\end{array}$ \\
\hline & FZB24 ${ }^{\circledR} \mathrm{TB}$ & ABiTEP GmbH, Berlin, Ger-many & $\begin{array}{c}\text { Plant growth-promoting agent for plant } \\
\text { strengthening }\end{array}$ \\
\hline & Taegro $^{\circledR}$ & $\begin{array}{c}\text { Syngenta, Basel, previously } \\
\text { Novozyme, Davis, California, and } \\
\text { Earth Biosciences }\end{array}$ & $\begin{array}{l}\text { EPA-registered biofungicide for use in } \\
\text { North America }\end{array}$ \\
\hline \multirow{2}{*}{$\begin{array}{l}\text { B. velezensis GB03 } \\
\text { (previously B. subtilis GB03) }\end{array}$} & Kodiak $^{\mathrm{TM}}$ & $\begin{array}{c}\text { Bayer Crop Science, North } \\
\text { Carolina, NC }\end{array}$ & $\begin{array}{l}\text { EPA-registered biological seed treatment } \\
\text { fungicide with demonstrable PGR activity. } \\
\text { Efficient in cotton, beans, and vegetables }\end{array}$ \\
\hline & Companion & $\begin{array}{l}\text { Growth Products Ltd., White } \\
\text { Plains, NY }\end{array}$ & $\begin{array}{l}\text { EPA-registered biofungicide that prevents } \\
\text { and controls plant diseases }\end{array}$ \\
\hline \multirow[b]{2}{*}{$\begin{array}{c}\text { B. velezensis D747 } \\
\text { (previously B. amyloliquefaciens } \\
\text { D747) }\end{array}$} & Double Nickel $55^{\mathrm{TM}}$ & Certis Columbia, MD, U.S.A. & $\begin{array}{l}\text { EPA-registered biofungicide for control or } \\
\text { suppression of fungal and bacterial plant }\end{array}$ \\
\hline & Amylo- $X^{\circledR}$ & $\begin{array}{l}\text { Certis Columbia, MD } \\
\text { USA/Intrachem Bio Italia SpA }\end{array}$ & $\begin{array}{c}\text { Biocontrol of Botrytis and other fungal } \\
\text { diseases of grapes, strawberries, and } \\
\text { vegetables, and bacterial diseases, such as } \\
\text { fire blight in pome fruit and PSA in } \\
\text { kiwi fruit }\end{array}$ \\
\hline
\end{tabular}

Apart from the aforementioned uses, the members of OGBa have also been applied as biocontrol agents against parasitic nematodes and protist pathogens. In 2008, B. velezensis FZB42 was reported to reduce nematode eggs in roots, juvenile worms in soil and plant galls on tomato [84]. Genomic study revealed that the whole genome of B. velezensis FZB42 encoded a diverse spectrum of different antimicrobial compounds able to suppress harmful nematodes living within the plant rhizosphere [85]. In controlling the protist pathogen, 
B. velezensis HB-26 (previously B. amyloliquefaciens HB-26) showed promising capability for controlling Plasmodiophora brassicae, a root-infecting protist that causes clubroot disease in brassica species. Many antimicrobial compounds showing specific activities against $P$. brassicae were found in the genome of $B$. velezensis HB-26 [86]. Overall, much more focus is still needed to fulfill the understanding of the molecular basis for the ability of members of OGBa to inhibit nematodes and protists beyond in silico genomic studies. Understanding such attributes will help to shed light on the functionalities as well as the biological roles of antimicrobial compounds from OGBa not only for improved plant growth but as biocontrol agents to minimize the proliferation of plant pathogens including viruses, bacteria, fungus, nematodes, and protists.

\subsection{Source of Commercial Enzymes}

Microbial enzymes such as $\alpha$-amylase, protease, and lipase have been used in various biotechnological applications including textile applications, feed industry, food industry, and organic synthesis [87-89]. The U.S. Food and Drug Administration (FDA) in 1999 reported that enzymes such as $\alpha$-amylase and protease originating from B. subtilis are Generally Recognized as Safe (GRAS) for use as direct food ingredients [90]. As members of the $B$. subtilis species complex, OGBa bacteria are a potent bacterial group due to their abilities to produce various types of enzymes including $\alpha$-amylase, protease, lipase, cellulase, xylanase, pectinase, aminotransferase, barnase, peroxidase, and laccase (Table 4).

Table 4. Various types of enzymes produced by members of the operational group Bacillus amyloliquefaciens.

\begin{tabular}{ccc}
\hline Bacterial Species & Enzymes & Reference \\
\hline B. amyloliquefaciens KCP2 & $\alpha$-amylase and protease & {$[91]$} \\
B. amyloliquefaciens NRRL 942 & $\alpha$-amylase & {$[92]$} \\
B. siamensis JJC33M & $\alpha$-amylase & {$[93]$} \\
B. velezensis 157 & $\alpha$-amylase, cellulase, xylanase and pectinase & {$[94]$} \\
B. velezensis 275 & Cellulase, xylanase, peroxidase, and laccase & {$[95]$} \\
B. velezensis AP194 & Pectinase & {$[96]$} \\
B. velezensis AP214 & Pectinase & {$[96]$} \\
B. velezensis GZB & Laccase & {$[97]$} \\
B. velezensis JJ-D34 & $\alpha$-amylase, protease and cellulase & {$[98]$} \\
B. velezensis Jxnuwx-1 & Protease & {$[99]$} \\
B. velezensis SB1216 & Barnase & {$[100]$} \\
B. velezensis SPZ1 & Lipase & {$[101]$} \\
B. velezensis SYBC H47 & Aminotransferase & {$[102]$} \\
B. velezensis ZL918 & $\alpha$-amylase & {$[103]$} \\
\hline
\end{tabular}

\subsection{Antimicrobial Compounds Producer}

The increment in the global antibiotic-resistant pathogens has led to the exploration of compounds with alternative therapeutic strategies [104]. The members of OGBa were reported to produce antimicrobial compounds used in the suppression of pathogens [45]. The antimicrobial compounds produced by the member of OGBa have been reviewed previously $[8,105]$. The members of OGBa produced some important antimicrobial compounds (Figure 3), including non-ribosomal peptides (surfactin, fengycin, bacillomycin-D, bacilysin and bacillibactin) and polyketides (bacillaene, macrolactin and difficidin) [6,105]. 


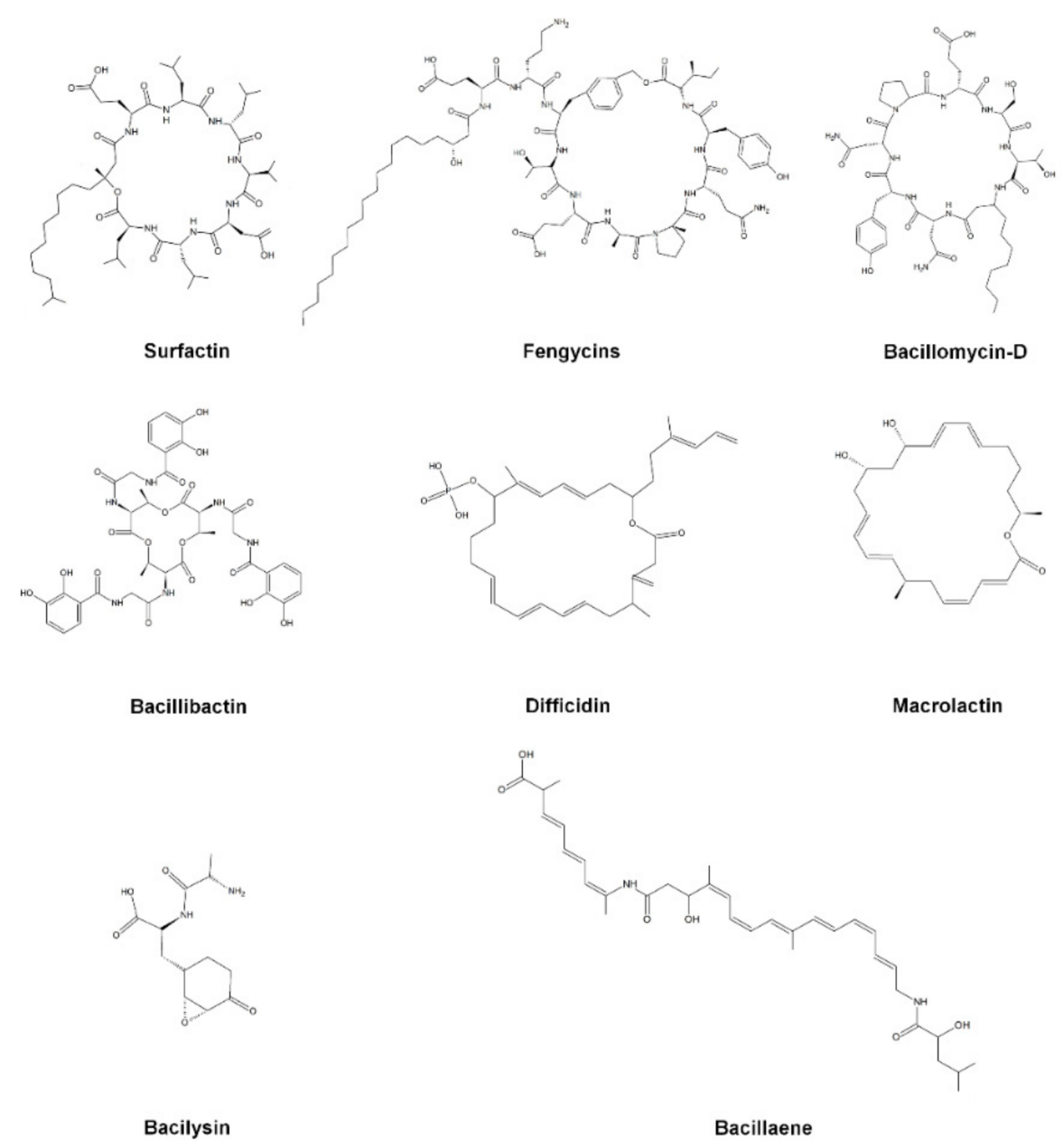

Figure 3. Antimicrobial compounds produced by members of the operational group Bacillus amyloliquefaciens.

Non-ribosomal peptides produced by bacteria and fungi contain two or more moieties derived from amino acids [106]. The mode of action of non-ribosomal peptides involves the disruption to the cell membrane and inhibition on the transfer of peptidoglycan precursors to bactoprenol pyrophosphate [107]. In 2019, surfactins from B. velezensis 9D-6 were found to inhibit the in vitro growth of bacteria (B. cereus, C. michiganensis, Pantoea agglomerans, Ralstonia solanacearum, Xanthomonas campestris and Xanthomonas euvesicatoria) and fungi (Alternaria solani, Cochliobolus carbonum, F. oxysporum, F. solani, Gibberella pulicaris, Gibberella zeae, Monilinia fructicola, Pyrenochaeta terrestris and R. solani) pathogens [108]. In another related study, in silico genomic study of B. siamensis JFL15 had gene clusters involved in the biosynthesis of antimicrobial compounds. The LC-MS/MS analysis confirmed the presence of iturin A and bacillomycin F. Both compounds showed strong antifungal activities against Magnapothe grisea, R. solani and Colletotrichum gloeosporioides, as analyzed under in vitro conditions [109]. Moreover, the presence of fengycin, bacilysin, and bacillibactin had also been reported from $B$. velezensis OSY-S3 that showed inhibition activities against Listeria innocua, Escherichia coli, Penicillium sp., Cladosporium sp., and Staphylococcus aureus [110].

Polyketides are biopolymers of acetate and other short carboxylates that are biosynthesized by polyketide synthases, a natural metabolite produced by microorganisms and plants which possess various antifungal and antibacterial activities [111,112]. Since the discovery of polyketides (e.g., streptomycin in 1950), the exploration of new polyketides has assisted pharmaceutical companies in isolating new antibiotic-producing strains as the main sources of antibiotics [113]. Antibacterial polyketides including bacillaene, macrolactin and difficidin were reported from B. velezensis OSY-GA1 [109]. Moreover, B. velezensis YJ11-1-4 isolated from doenjang exhibited good antimicrobial activities against bacterial 
(B. cereus, E. coli, Listeria monocytogenes and S. aureus) and fungal (Aspergillus flavus subsp. flavus) foodborne pathogens. Genomic analysis reveals the presence of antibiotic biosynthesis operons including bacillaene, macrolactin and difficidin in the genome of $B$. velezensis OSY-GA1 [114]. Additionally, four new glycosylated macrolactin compounds, namely macrolactins $\mathrm{O}, \mathrm{P}, \mathrm{Q}$ and $\mathrm{R}$, had been isolated from the liquid cultures of $B$. velezensis AH159-1. These compounds inhibited S. aureus peptide deformylase and also showed antibacterial activities against E. coli and S. aureus [115].

\subsection{Potential as Probiotics}

Probiotics are live microbial feed supplements that benefit the host animal by improving the microbial balance. Probiotics have become increasingly popular due to continuously expanding scientific evidence pointing to their beneficial effects on both humans and animals [116]. Within the OGBa, some $B$. velezensis strains are reported to display probiotic potential and have been applied as probiotics for animals [117]. For instance, B. velezensis H57 (previously B. amyloliquefaciens H57) isolated from lucerne was first investigated in the research to prevent fungal spoilage of hay [118]. Because it is an endospore-forming bacterium able to produce antimicrobial compounds, B. velezensis $\mathrm{H} 57$ was commercialized as a spoilage control agent under the product name HayRite ${ }^{\mathrm{TM}}$ (Biocare and BASF, Australia). Interestingly, sheep and cattle fed on HayRite ${ }^{\mathrm{TM}}$ showed improvements in digestibility and nitrogen retention leading to increased weight gain [118]. Genomically, the potential of $B$. velezensis $\mathrm{H} 57$ to synthesize antimicrobial compounds including surfactin (srf $A B C D)$, iturin (itu $A B C D)$, bacillomycin $\mathrm{D}($ bmy $A B C)$, fengycin (fen $A B C D E)$, macrolactin (mln $A B C D E F G H I)$, difficidin (dfnABCDEFGHIJ) and bacillaene (baeEDLMNJRS) were suggested to facilitate the probiotic effects of $B$. velezensis H57 [27]. In another related study, B. velezensis FTC01 manifested itself as a probiotic [119]. Genes coding for hydrolases (peptidases, phytases and glycosidases) that can improve feed digestion and prevent intestinal disorders are present in the genome of $B$. velezensis FTC01. Additionally, peptidylprolyl isomerase (prs $A$ ) gene (a gene that is involved in bacterial adhesion and signaling of biofilm formation in the host gut) was also found. Moreover, in silico genome analysis of B. velezensis FTC01 proved the presence of gene clusters involved in the synthesis of antimicrobial peptides. Similarly, gene clusters involved in the synthesis of antimicrobial peptides were also found in the genome of B. velezensis JT3-1, a probiotic strain isolated from faeces of the domestic yak [21]. The antimicrobial activity of $B$. velezensis JT3-1 was confirmed using an antimicrobial assay. Strain JT3-1 manifested strong antagonistic activities against various intestinal pathogenic flora including L. monocytogenes, S. aureus, E. coli, Salmonella typhimurium, Mannheimia haemolytica, Staphylococcus hominis, Clostridium perfringens and Mycoplasma bovis.

B. velezensis B-1895 (previously B. amyloliquefaciens B-1895) has been commercially used as a probiotic in the fish industry, particularly for Alburnus leobergi [120,121]. Its probiotic potential was proven thought the Ames test (reported as non-mutagenic) and antimicrobial activities (against Streptococcus intermedius and Porphyromonas gingivalis). Moreover, the endospores of $B$. velezensis B-1895 were found tolerant to $0.3 \%(w / v)$ bile salts and survived incubation for $4 \mathrm{~h}$ in MRS broth at $\mathrm{pH}$ 2.0-3.0. Overall, the results suggested the potential of $B$. velezensis B-1895 as a fish probiotic [122]. In another related study, $B$. velezensis JW also manifested itself as a fish probiotic [123]. Strain JW showed antibacterial activities against a broad range of bacterial fish pathogens (Aeromonas hydrophila, Aeromonas salmonicida, Lactococcus garvieae, Streptococcus agalactiae and Vibrio parahemolyticus). Dietary administration of $B$. velezensis JW induced an immune response in Carassius auratus. The immune-related genes in $C$. auratus such as interferon gamma gene (IFN- $\gamma$ ), tumor necrosis factor- $\alpha$ (TNF- $\alpha$ ), interleukin-1 (IL-1), interleukin-4 (IL-4) and interleukin-10 (IL-10) were found to be upregulated by $B$. velezensis JW-supplemented diets. It is noteworthy that $C$. auratus fed with $B$. velezensis JW-supplemented diets showed improvements in survival rate after $A$. hydrophila infection. This was supported genomically by the presence of antimicrobial gene clusters in the genome of B. velezensis JW [122]. Moreover, a potential probiotic effect of $B$. velezensis V4 on the growth performance of Oncorhynchus mykiss 
had also been investigated [124]. Cell-free supernatant of B. velezensis V4 with anti- $A$. salmonicida was shown to contain antimicrobial compounds including iturin, macrolactin and difficidin. The mortality rate of O. mykiss was reduced by $27 \%$ and the weight gain ratio was increased by $71 \%$ through the $1 \%(v / w)$ addition of $B$. velezensis V4. Overall, the findings demonstrated that $B$. velezensis $\mathrm{V} 4$ was an effective probiotic in O. mykiss.

The commercialization of $B$. amyloliquefaciens as a probiotic in aquaculture is not as common compared to its agricultural applications (Table 3). Ecobiol ${ }^{\circledR}$ Soluble Plus, is one of the commercial probiotic products reported as containing B. amyloliquefaciens at a concentration of $10^{9} \mathrm{CFU} / \mathrm{g}$, specifically formulated for applications in poultry and swine, as well as in aquaculture. There was research conducted on the commercial probiotic Ecobiol ${ }^{\circledR}$ Soluble to observe its positive effects on the biofloc culture of Litopenaeus vannamei and its benefits on water quality, growth performance and the immune system of shrimps. Three doses of probiotic $\left(9.48 \times 10^{4}, 1.90 \times 10^{5}\right.$ and $\left.3.79 \times 10^{5} \mathrm{CFU} / \mathrm{g}\right)$ were applied to the culture water for 42 days. At the end of the trial, there was no significant improvement in the water quality. However, it showed notable changes in the immune system of the shrimp. As compared to the control treatment, there was an increase in the total protein concentration and granular hemocytes, and a decrease in the cell number with apoptosis in the hemolymph in all treatments. Therefore, other than being mixed with feed, $B$. amyloliquefaciens in the commercial probiotic Ecobiol ${ }^{\circledR}$ Soluble Plus could also be applied directly to the culture system; this research proved it provided better resistance to shrimps against the outbreak of pathogens in shrimp biofloc systems [125].

There is much ongoing research on the development and formulations of bacterial strains belonging to the OGBa as potential probiotics for commercialization purposes in the aquaculture industry. Most of the studies have emphasized probiotic feed formulations, feeding trials on a small scale before moving to field trials. For instance, dietary inclusion of B. amyloliquefaciens at $10^{6} \mathrm{CFU} / \mathrm{g}$ fed to zebra fish improved the expression levels of metabolism-related genes, enzyme activities and oxidative stress-related genes in the fish liver as well as enhanced their immune resistance against pathogenic $A$. hydrophila and S. agalactiae. In addition, the strain of $B$. amyloliquefaciens used in this study was able to express recombinant xylanase, an important enzyme that aided in better feed digestibility and efficiency [126]. In another related study, the administration of B. amyloliquefaciens $\left(1 \times 10^{9} \mathrm{CFU} / \mathrm{g}\right)$, together with Spirulina platensis in formulated diet for tilapia, improved growth performance and feed utilization after a 60 day feeding trial. The mRNA level of the TNF- $\alpha$ gene and the transcription of $S O D$ were considerably higher in tilapia fed with dietary B. amyloliquefaciens and S. platensis compared to the control group [127]. Moreover, B. amyloliquefaciens at a concentration of $10^{6} \mathrm{CFU} / \mathrm{mL}$ provided significant protection to juvenile blue swimming crabs, Portunus pelagicus, when challenged with Vibrio harveyi in in vivo trials [128]. Nevertheless, further studies are necessary, mainly on probiotic formulation along with larger field trials, to strengthen the outcomes in order to be able to commercialize bacterial strains belonging to the OGBa for aquaculture use.

In vivo and field trials are critical in probiotic development. Occasionally, there were negative outcomes in in vivo studies which were carried out based upon the positive results acquired from the preliminary in vitro assays, which indicated the possibility of negative correlations between trials in vitro and in vivo. Hence, it is crucial to understand and to optimize various conditions in in vivo studies or field trials including the probiotic formulation which may affect the survival, colonization, proliferation, and interaction of the probiotic with the host in a certain environment [129].

\subsection{Potential as Bioremediation Agents}

The use of microorganisms as bioremediation agents has become a burgeoning trend [130]. To date, most research focused on the plant growth-promoting activity and antimicrobial compounds of OGBa is as described above. Interestingly, in 2019, B. amyloliquefaciens YP6 was reported to exhibit both plant growth-promoting activity and broadspectrum organophosphorus pesticide (OP) removal [131]. In silico genome analysis of $B$. 
amyloliquefaciens YP6 found it to contain a variety of promising genes, including phosphorus solubilizing and $\mathrm{OP}$-degrading related genes $(p h o \mathrm{D}, p h o \mathrm{~A}, p h r \mathrm{C}, p h o \mathrm{E}, y c s \mathrm{E}, b c r \mathrm{C}$ and $y v a \mathrm{~K})$, indole-3-acetic acid synthesis related genes ( $\operatorname{mhh} \mathrm{X}, \operatorname{cgeE}$ and eps $\mathrm{M})$, and siderophores synthesis related genes (ent $\mathrm{B}, m e n \mathrm{~F}, e n t \mathrm{C}$ and $e n t \mathrm{~A})$. The results hinted at the potential application of B. amyloliquefaciens YP6 in agricultural and environmental remediations. Overall, much more focus is still needed to understand the OP-degrading related genes beyond in silico genome analysis. Therefore, it is necessary to conduct further studies to determine the in vitro functional genomics and the OP-degrading enzyme activities of the members of OGBa. Understanding such attributes will help to shed light on the applicability of the OGBa in OPs degradation and in the bioremediation processes as a whole.

\section{Concluding Remark and Future Perspectives}

In conclusion, the progress of the research on the biotechnological applications of bacterial species that belong to OGBa is remarkable. The bacteria are important not only industrially, but also environmentally. A plethora of studies have addressed the abilities of the members of OGBa as plant growth-promoters, biocontrol agents, probiotics, bioremediation agents as well as producers of commercial enzymes and antibiotics. Moreover, the use of the bacteria in optimized bioformulations as well as the demonstration of the great success of the commercialized products give us hope towards more sustainable agricultural and aquacultural industries. Owing to the listed biotechnological applications and potentials, more research should be done focusing on the integration of system biology data derived from genomics, phenomics, proteomics, metabolomics and fluxomic analyses in order to expand our basic understanding on the versatility of the members of OGBa. Enabling the prediction of cellular functions and metabolites produced by the members of this operational group could provide fundamental knowledge towards the enhancement of the applications of their potentials in biotechnology and bioprocessing for the benefit of all.

Supplementary Materials: The following are available online at https:/ / www.mdpi.com/2076-260 7/9/3/614/s1: Table S1. Bacterial strains from the operational group Bacillus amyloliquefaciens.

Author Contributions: Conceptualization, M.S.N. and S.S.; writing-original draft preparation, M.S.N.; writing—review and editing, M.S.N., R.S.R.Y., M.M.A.-a.B., S.M.Y., M.K., S.A.A. and S.S.; visualization, M.S.N., R.S.R.Y., M.M.A.-a.B., S.M.Y., M.K., S.A.A. and S.S.; supervision, S.S.; project administration, S.S.; funding acquisition, S.S. All authors have read and agreed to the published version of the manuscript.

Funding: This study was funded by the UPM-Putra Graduate Initiative (GP-IPS/2018/9601400). M.S.N., R.S.R.Y. and M.M.A.B. were sponsored by Graduate Research Fellowships (GRF) from Universiti Putra Malaysia.

Institutional Review Board Statement: Not applicable.

Informed Consent Statement: Not applicable.

Data Availability Statement: Not applicable.

Acknowledgments: Not applicable.

Conflicts of Interest: The authors declare no conflict of interest.

\section{References}

1. Priest, F.G.; Goodfellow, M.; Shute, L.A.; Berkeley, R.C.W. Bacillus amyloliquefaciens sp. nov., nom. rev. Int. J. Syst. Evol. Microbiol. 1987, 37, 69-71. [CrossRef]

2. Fukumoto, J. Studies on the production of bacterial amylase. I. Isolation of bacteria secreting potent amylases and their distribution. Nippon. Nogeikagaku Kaishi 1943, 19, 487-503.

3. Berkeley, R.C.W.; Logan, N.A.; Shute, L.A.; Capey, A.G. Identification of Bacillus species. In Methods in Microbiology; Academic Press: Landon, UK, 1984; Volume 16, pp. 292-328.

4. Fan, B.; Blom, J.; Klenk, H.P.; Borriss, R. Bacillus amyloliquefaciens, Bacillus velezensis, and Bacillus siamensis form an "operational group B. amyloliquefaciens" within the B. subtilis species complex. Front. Microbiol. 2017, 8, 22. [CrossRef] 
5. Dunlap, C.A.; Kim, S.J.; Kwon, S.W.; Rooney, A.P. Bacillus velezensis is not a later heterotypic synonym of Bacillus amyloliquefaciens; Bacillus methylotrophicus, Bacillus amyloliquefaciens subsp. plantarum and 'Bacillus oryzicola'are later heterotypic synonyms of Bacillus velezensis based on phylogenomic. Int. J. Syst. Evol. Microbiol. 2016, 66, 1212-1217. [CrossRef] [PubMed]

6. Dunlap, C.A.; Bowman, M.J.; Rooney, A.P. Iturinic lipopeptide diversity in the Bacillus subtilis species group-Important antifungals for plant disease biocontrol applications. Front. Microbiol. 2019, 10, 1794. [CrossRef] [PubMed]

7. Ye, M.; Tang, X.; Yang, R.; Zhang, H.; Li, F.; Tao, F.; Li, F.; Wang, Z. Characteristics and application of a novel species of Bacillus: Bacillus velezensis. ACS Chem. Biol. 2018, 13, 500-505. [CrossRef] [PubMed]

8. Rabbee, M.F.; Sarafat Ali, M.; Choi, J.; Hwang, B.S.; Jeong, S.C.; Baek, K.H. Bacillus velezensis: A valuable member of bioactive molecules within plant microbiomes. Molecules 2019, 24, 1046. [CrossRef] [PubMed]

9. Auch, A.F.; von Jan, M.; Klenk, H.P.; Göker, M. Digital DNA-DNA hybridization for microbial species delineation by means of genome-to-genome sequence comparison. Stand. Genomic Sci. 2010, 2, 117-134. [CrossRef]

10. Connor, N.; Sikorski, J.; Rooney, A.P.; Kopac, S.; Koeppel, A.F.; Burger, A.; Cole, S.G.; Perry, E.B.; Krizanc, D.; Field, N.C.; et al. Ecology of speciation in the genus Bacillus. Appl. Environ. Microbiol. 2010, 76, 1349-1358. [CrossRef]

11. Borriss, R.; Chen, X.H.; Rueckert, C.; Blom, J.; Becker, A.; Baumgarth, B.; Fan, B.; Pukall, R.; Schumann, P.; Spröer, C.; et al. Relationship of Bacillus amyloliquefaciens clades associated with strains DSM7 ${ }^{\mathrm{T}}$ and $\mathrm{FZB} 42^{\mathrm{T}}$ : A proposal for Bacillus amyloliquefaciens subsp. amyloliquefaciens subsp. nov. and Bacillus based on complete genome sequence comparisons. Int. J. Syst. Evol. Microbiol. 2011, 61, 1786-1801. [CrossRef]

12. Chun, J.; Bae, K.S. Phylogenetic analysis of Bacillus subtilis and related taxa based on partial gyrA gene sequences. Antonie Van Leeuwenhoek 2000, 78, 123-127. [CrossRef]

13. Reva, O.N.; Dixelius, C.; Meijer, J.; Priest, F.G. Taxonomic characterization and plant colonizing abilities of some bacteria related to Bacillus amyloliquefaciens and Bacillus subtilis. FEMS Microbiol. Ecol. 2004, 48, 249-259. [CrossRef] [PubMed]

14. Ngalimat, M.S.; Sabri, S. Taxonomic note: Speciation within the operational group Bacillus amyloliquefaciens based on comparative phylogenies of housekeeping genes. Asia-Pac. J. Mol. Biol. Biotechnol. 2020, 28, 19-26. [CrossRef]

15. Kumar, S.; Stecher, G.; Li, M.; Knyaz, C.; Tamura, K. MEGA X: Molecular evolutionary genetics analysis across computing platforms. Mol. Biol. Evol. 2018, 35, 1547-1549. [CrossRef] [PubMed]

16. Sumpavapol, P.; Tongyonk, L.; Tanasupawat, S.; Chokesajjawatee, N.; Luxananil, P.; Visessanguan, W. Bacillus siamensis sp. nov., isolated from salted crab (poo-khem) in Thailand. Int. J. Syst. Evol. Microbiol. 2010, 60, 2364-2370. [CrossRef]

17. Ruiz-García, C.; Béjar, V.; Martinez-Checa, F.; Quesada, E. Bacillus velezensis sp nov., a surfactant-producing bacterium isolated from the river velez in malaga, southern Spain. Int. J. Syst. Evol. Microbiol. 2005, 55, 191-195. [CrossRef]

18. Dunlap, C.A.; Saunders, L.P.; Schisler, D.A.; Leathers, T.D.; Naeem, N.; Cohan, F.M.; Rooney, A.P. Bacillus nakamurai sp. nov., a black-pigment-producing strain. Int. J. Syst. Evol. Microbiol. 2016, 66, 2987-2991. [CrossRef]

19. Liu, B.; Ge, B.; Azhar, N.; Zhao, W.; Cui, H.; Zhang, K. Complete genome sequence of Bacillus methylotrophicus strain NKG-1, isolated from the changbai mountains, China. Genome Announc. 2018, 6, e01454-17. [CrossRef]

20. Balderas-Ruíz, K.A.; Bustos, P.; Santamaria, R.I.; González, V.; Cristiano-Fajardo, S.A.; Barrera-Ortíz, S.; Mezo-Villalobos, M.; Aranda-Ocampo, S.; Guevara-García, Á.A.; Galindo, E.; et al. Bacillus velezensis 83 a bacterial strain from mango phyllosphere, useful for biological control and plant growth promotion. AMB Express 2020, 10, 163. [CrossRef]

21. Li, Y.; Li, X.; Jia, D.; Liu, J.; Wang, J.; Liu, A.; Liu, Z.; Guan, G.; Liu, G.; Luo, J.; et al. Complete genome sequence of Bacillus velezensis JT3-1, a microbial germicide isolated from yak feces. bioRxiv 2019, 1, 555219. [CrossRef] [PubMed]

22. Nannan, C.; Gillis, A.; Caulier, S.; Mahillon, J. Complete genome sequence of Bacillus velezensis CN026 exhibiting antagonistic activity against Gram-negative foodborne pathogens. Genome Announc. 2018, 6, e01543-17. [CrossRef] [PubMed]

23. Zhang, Y.; Wang, Y.; Qin, Y.; Li, P. Complete genome sequence of Bacillus velezensis LPL-K103, an antifungal cyclic lipopeptide bacillomycin L producer from the surface of lemon. 3 Biotech 2020, 10, 8. [CrossRef]

24. Zeng, Q.; Xie, J.; Li, Y.; Chen, X.; Wang, Q. Draft genome sequence of an endophytic biocontrol bacterium, Bacillus velezensis PG12, isolated from apple fruit. Microbiol. Resour. Announc. 2019, 8, e00468-19. [CrossRef] [PubMed]

25. Gamez, R.M.; Rodríguez, F.; Bernal, J.F.; Agarwala, R.; Landsman, D.; Mariño-Ramírez, L. Genome sequence of the banana plant growth-promoting rhizobacterium Bacillus amyloliquefaciens BS006. Genome Announc. 2015, 3, e01391-15. [CrossRef] [PubMed]

26. Chen, L.; Shi, H.; Heng, J.; Wang, D.; Bian, K. Antimicrobial, plant growth-promoting and genomic properties of the peanut endophyte Bacillus velezensis LDO2. Microbiol. Res. 2019, 218, 41-48. [CrossRef] [PubMed]

27. Schofield, B.J.; Skarshewski, A.; Lachner, N.; Ouwerkerk, D.; Klieve, A.V.; Dart, P.; Hugenholtz, P. Near complete genome sequence of the animal feed probiotic, Bacillus amyloliquefaciens H57. Stand. Genomic Sci. 2016, 11, 60. [CrossRef] [PubMed]

28. Cai, X.; Kang, X.; Xi, H.; Liu, C.; Xue, Y. Complete genome sequence of the endophytic biocontrol strain Bacillus velezensis CC09. Genome Announc. 2016, 4, e01048-16. [CrossRef] [PubMed]

29. Geng, W.; Cao, M.; Song, C.; Xie, H.; Liu, L.; Yang, C.; Feng, J.; Zhang, W.; Jin, Y.; Du, Y.; et al. Complete genome sequence of Bacillus amyloliquefaciens LL3, which exhibits glutamic acid-independent production of poly- $\gamma$-glutamic acid. J. Bacteriol. 2011, 193, 3393-3394. [CrossRef] [PubMed]

30. Deng, Q.; Wang, R.; Sun, D.; Sun, L.; Wang, Y.; Pu, Y.; Fang, Z.; Xu, D.; Liu, Y.; Ye, R.; et al. Complete genome of Bacillus velezensis CMT-6 and comparative genome analysis reveals lipopeptide diversity. Biochem. Genet. 2020, 58, 1-15. [CrossRef] [PubMed] 
31. Khalaf, E.M.; Raizada, M.N. Draft genome sequences of Bacillus and Paenibacillus species isolated from seeds of Citrullus lanata (watermelon), Cucurbita moschata (butternut squash), and Cucurbita pepo L. var pepo L. (pumpkin). Microbiol. Resour. Announc. 2020, 9, e00727-20. [CrossRef] [PubMed]

32. Zhao, X.; Zhou, Z.; Han, Y.; Wang, Z.; Fan, J.; Xiao, H. Isolation and identification of antifungal peptides from Bacillus BH072, a novel bacterium isolated from honey. Microbiol. Res. 2013, 168, 598-606. [CrossRef]

33. Ngalimat, M.S.; Rahman, R.N.Z.R.A.; Yusof, M.T.; Syahir, A.; Sabri, S. Characterisation of bacteria isolated from the stingless bee, Heterotrigona itama, honey, bee bread and propolis. PeerJ 2019, 7, e7478. [CrossRef] [PubMed]

34. Zulkhairi Amin, F.A.; Sabri, S.; Ismail, M.; Chan, K.W.; Ismail, N.; Mohd Esa, N.; Mohd Lila, M.A.; Zawawi, N. Probiotic properties of Bacillus strains isolated from stingless bee (Heterotrigona itama) honey collected across Malaysia. Int. J. Environ. Res. Public Health 2020, 17, 278. [CrossRef]

35. Kalinowski, J.; Ahrens, B.; Al-Dilaimi, A.; Winkler, A.; Wibberg, D.; Schleenbecker, U.; Rückert, C.; Wölfel, R.; Grass, G. Isolation and whole genome analysis of endospore-forming bacteria from heroin. Forensic Sci. Int. Genet. 2018, 32, 1-6. [CrossRef] [PubMed]

36. Lim, S.B.Y.; Junqueira, A.C.M.; Uchida, A.; Purbojati, R.W.; Houghton, J.N.I.; Chénard, C.; Wong, A.; Kolundžija, S.; Clare, M.E.; Kushwaha, K.K.; et al. Genome sequence of Bacillus velezensis SGAir0473, isolated from tropical air collected in Singapore. Genome Announc. 2018, 6, e00642-18. [CrossRef] [PubMed]

37. Guo, W.; Cui, P.; Chen, X. Complete genome of Bacillus sp. Pc3 isolated from the Antarctic seawater with antimicrobial activity. Mar. Genomics 2015, 20,1-2. [CrossRef]

38. Agersø, Y.; Stuer-Lauridsen, B.; Bjerre, K.; Jensen, M.G.; Johansen, E.; Bennedsen, M.; Brockmann, E.; Nielsen, B. Antimicrobial susceptibility testing and tentative epidemiological cutoff values for five Bacillus species relevant for use as animal feed additives or for plant protection. Appl. Enviromental Microbiol. 2018, 84, e01108-18.

39. Pan, H.Q.; Li, Q.L.; Hu, J.C. The complete genome sequence of Bacillus velezensis 9912D reveals its biocontrol mechanism as a novel commercial biological fungicide agent. J. Biotechnol. 2017, 247, 25-28. [CrossRef] [PubMed]

40. Guo, Y.; Zhou, J.; Tang, Y.; Ma, Q.; Zhang, J.; Ji, C.; Zhao, L. Characterization and genome analysis of a zearalenone-degrading Bacillus velezensis strain ANSB01E. Curr. Microbiol. 2020, 77, 273-278. [CrossRef] [PubMed]

41. Wu, J.; Xu, G.; Jin, Y.; Sun, C.; Zhou, L.; Lin, G.; Xu, R.; Wei, L.; Fei, H.; Wang, D.; et al. Isolation and characterization of Bacillus sp. GFP-2, a novel Bacillus strain with antimicrobial activities, from whitespotted bamboo shark intestine. AMB Express 2018, 8, 84. [CrossRef]

42. Molinatto, G.; Franzil, L.; Steels, S.; Puopolo, G.; Pertot, I.; Ongena, M. Key impact of an uncommon plasmid on Bacillus amyloliquefaciens subsp. plantarum S499 developmental traits and lipopeptide production. Front. Microbiol. 2017, 8, 17. [CrossRef]

43. Feng, J.; Gu, Y.; Wang, J.; Song, C.; Yang, C.; Xie, H.; Zhang, W.; Wang, S. Curing the plasmid pMC1 from the poly ( $\gamma$-glutamic acid) producing Bacillus amyloliquefaciens LL3 strain using plasmid incompatibility. Appl. Biochem. Biotechnol. 2013, 171, 532-542. [CrossRef]

44. Chun, B.H.; Kim, K.H.; Jeong, S.E.; Jeon, C.O. Genomic and metabolic features of the Bacillus amyloliquefaciens group- B. amyloliquefaciens, B. velezensis, and B. siamensis- revealed by pan-genome analysis. Food Microbiol. 2019, 77, 146-157. [CrossRef]

45. Belbahri, L.; Chenari Bouket, A.; Rekik, I.; Alenezi, F.N.; Vallat, A.; Luptakova, L.; Petrovova, E.; Oszako, T.; Cherrad, S.; Vacher, S.; et al. Comparative genomics of Bacillus amyloliquefaciens strains reveals a core genome with traits for habitat adaptation and a secondary metabolites rich accessory genome. Front. Microbiol. 2017, 8, 1438. [CrossRef] [PubMed]

46. Kashyap, B.K.; Solanki, M.K.; Pandey, A.K.; Prabha, S.; Kumar, P.; Kumari, B. Bacillus as plant growth promoting rhizobacteria (PGPR): A promising green agriculture technology. In Plant Health under Biotic Stress; Springer Nature Singapore Pte Ltd.: Singapore, 2019; pp. 219-236.

47. Chowdhury, S.P.; Hartmann, A.; Gao, X.; Borriss, R. Biocontrol mechanism by root-associated Bacillus amyloliquefaciens FZB42-A Review. Front. Microbiol. 2015, 6, 780. [CrossRef] [PubMed]

48. Sibponkrung, S.; Kondo, T.; Tanaka, K.; Tittabutr, P.; Boonkerd, N.; Yoshida, K.I.; Teaumroong, N. Co-inoculation of Bacillus velezensis strain S141 and Bradyrhizobium strains promotes nodule growth and nitrogen fixation. Microorganisms 2020, 8, 678. [CrossRef]

49. Kim, S.Y.; Song, H.; Sang, M.K.; Weon, H.Y.; Song, J. The Complete genome sequence of Bacillus velezensis strain GH1-13 reveals agriculturally beneficial properties and a unique plasmid. J. Biotechnol. 2017, 259, 221-227. [CrossRef] [PubMed]

50. Lu, K.; Jin, Q.; Lin, Y.; Lu, W.; Li, S.; Zhou, C.; Jin, J.; Jiang, Q.; Ling, L.; Xiao, M. Cell-free fermentation broth of Bacillus velezensis strain S3-1 improves pak choi nutritional quality and changes the bacterial community structure of the rhizosphere soil. Front. Microbiol. 2020, 11, 2043. [CrossRef]

51. Wang, C.; Zhao, D.; Qi, G.; Mao, Z.; Hu, X.; Du, B.; Liu, K.; Ding, Y. Effects of Bacillus velezensis FKM10 for promoting the growth of Malus hupehensis rehd. and inhibiting Fusarium verticillioides. Front. Microbiol. 2020, 10, 2889. [CrossRef]

52. Kumar, A.; Kumar, R.; Kumari, M.; Goldar, S. Enhancement of plant growth by using PGPR for a sustainable agriculture: A review. Int. J. Curr. Microbiol. Appl. Sci. 2020, 9, 152-165. [CrossRef]

53. Chowdhury, S.P.; Uhl, J.; Grosch, R.; Alquéres, S.; Pittroff, S.; Dietel, K.; Schmitt-Kopplin, P.; Borriss, R.; Hartmann, A. Cyclic lipopeptides of Bacillus amyloliquefaciens subsp. plantarum colonizing the lettuce rhizosphere enhance plant defense responses toward the bottom rot pathogen Rhizoctonia solani. Mol. Plant-Microbe Interact. 2015, 28, 984-995. [CrossRef] [PubMed] 
54. Li, B.; Li, Q.; Xu, Z.; Zhang, N.; Shen, Q.; Zhang, R. Responses of beneficial Bacillus amyloliquefaciens SQR9 to different soilborne fungal pathogens through the alteration of antifungal compounds production. Front. Microbiol. 2014, 5, 636. [CrossRef] [PubMed]

55. Fan, B.; Wang, C.; Song, X.; Ding, X.; Wu, L.; Wu, H.; Gao, X.; Borriss, R. Bacillus velezensis FZB42 in 2018: The Gram-positive model strain for plant growth promotion and biocontrol. Front. Microbiol. 2018, 9, 2491. [CrossRef]

56. Doornbos, R.F.; van Loon, L.C.; Bakker, P.A. Impact of root exudates and plant defense signaling on bacterial communities in the rhizosphere. a review. Agron. Sustain. Dev. 2012, 32, 227-243. [CrossRef]

57. Erlacher, A.; Cardinale, M.; Grosch, R.; Grube, M.; Berg, G. The impact of the pathogen Rhizoctonia solani and its beneficial counterpart Bacillus amyloliquefaciens on the indigenous lettuce microbiome. Front. Microbiol. 2014, 5, 175. [CrossRef]

58. Wang, S.; Wu, H.; Qiao, J.; Ma, L.; Liu, J.; Xia, Y.; Gao, X. Molecular mechanism of plant growth promotion and induced systemic resistance to Tobacco Mosaic Virus by Bacillus spp. J. Microbiol. Biotechnol. 2009, 19, 1250-1258. [CrossRef]

59. Jeong, H.; Jeong, D.E.; Kim, S.H.; Song, G.C.; Park, S.Y.; Ryu, C.M.; Park, S.H.; Choi, S.K. Draft genome sequence of the plant growth-promoting bacterium Bacillus siamensis KCTC 13613 ${ }^{\mathrm{T}}$. J. Bacteriol. 2012, 194, 4148-4149. [CrossRef]

60. Laird, M.; Piccoli, D.; Weselowski, B.; McDowell, T.; Renaud, J.; MacDonald, J.; Yuan, Z.C. Surfactin-producing Bacillus velezensis 1B-23 and Bacillus sp. 1D-12 protect tomato against bacterial canker caused by Clavibacter michiganensis subsp. michiganensis. J. Plant Pathol. 2019, 102, 451-458. [CrossRef]

61. Douriet-Gámez, N.R.; Maldonado-Mendoza, I.E.; Ibarra-Laclette, E.; Blom, J.; Calderón-Vázquez, C.L. Genomic analysis of Bacillus sp. strain B25, a biocontrol agent of maize pathogen Fusarium verticillioides. Curr. Microbiol. 2018, 75, 247-255. [CrossRef] [PubMed]

62. Dutta, S.; Surovy, M.Z.; Gupta, D.R.; Mahmud, N.U.; Chanclud, E.; Win, J.; Kamoun, S.; Islam, T. Genomic analyses reveal that biocontrol of wheat blast by Bacillus spp. may be linked with production of antimicrobial compounds and induced systemic resistance in host plants. Figshare 2018, 17, 1-48.

63. Cheng, M.; Xu, Q.; Li, Y.; Qin, H.; Chen, J. Antifungal activity and identification of active compounds of Bacillus amyloliquefaciens subsp. plantarum against Botryosphaeria dothidea. For. Pathol. 2016, 46, 561-568. [CrossRef]

64. Köberl, M.; White, R.A.; Erschen, S.; Spanberger, N.; El-Arabi, T.F.; Jansson, J.K.; Berg, G. Complete genome sequence of Bacillus amyloliquefaciens strain Co1-6, a plant growth-promoting rhizobacterium of Calendula officinalis. Genome Announc. 2015, 3 , e00862-15. [CrossRef]

65. Zhang, J.X.; Gu, Y.B.; Chi, F.M.; Ji, Z.R.; Wu, J.Y.; Dong, Q.L.; Zhou, Z.S. Bacillus amyloliquefaciens GB1 can effectively control apple valsa canker. Biol. Control 2015, 88, 1-7. [CrossRef]

66. Ma, J.; Liu, H.; Liu, K.; Wang, C.; Li, Y.; Hou, Q.; Yao, L.; Cui, Y.; Zhang, T.; Wang, H.; et al. Complete genome sequence of Bacillus velezensis GQJK49, a plant growth- promoting rhizobacterium with antifungal activity. Genome Announc. 2017, 5, e00922-17. [CrossRef] [PubMed]

67. Kim, J.D.; Jeon, B.J.; Han, J.W.; Park, M.Y.; Kang, S.A.; Kim, B.S. Evaluation of the endophytic nature of Bacillus amyloliquefaciens strain GYL4 and its efficacy in the control of anthracnose. Pest Manag. Sci. 2016, 72, 1529-1536. [CrossRef]

68. Jia, Z.; Jin, W.; Huang, Y.; Song, S. Complete genome sequence of Bacillus subtilis J-5, a potential biocontrol agent. Genome Announc. 2017, 5, e00275-17. [CrossRef] [PubMed]

69. Jing, R.; Li, N.; Wang, W.; Liu, Y. An endophytic strain JK of genus Bacillus isolated from the seeds of super hybrid rice (Oryza sativa L., Shenliangyou 5814) has antagonistic activity against rice blast pathogen. Microb. Pathog. 2020, 147, 104422. [CrossRef] [PubMed]

70. Sun, P.; Cui, J.; Jia, X.; Wang, W. Complete genome sequence of Bacillus velezensis L-1, which has antagonistic activity against pear diseases. Genome Announc. 2017, 5, e01271-17. [CrossRef]

71. Chen, L.; Heng, J.; Qin, S.; Bian, K. A Comprehensive understanding of the biocontrol potential of Bacillus velezensis LM2303 against Fusarium head blight. PLoS ONE 2018, 13, e0198560. [CrossRef]

72. Lee, S.Y.; Kim, B.Y.; Ahn, J.H.; Song, J.; Seol, Y.J.; Kim, W.G.; Weon, H.Y. Draft genome sequence of the biocontrol bacterium Bacillus amyloliquefaciens strain M27. J. Bacteriol. 2012, 194, 6934-6935. [CrossRef]

73. Zhang, Y.; Gao, X.; Wang, S.; Zhu, C.; Li, R.; Shen, Q. Application of Bacillus velezensis NJAU-Z9 enhanced plant growth associated with efficient rhizospheric colonization monitored by QPCR with primers designed from the whole genome sequence. Curr. Microbiol. 2018, 75, 1574-1583. [CrossRef]

74. Yuan, J.; Raza, W.; Shen, Q.; Huang, Q. Antifungal activity of Bacillus amyloliquefaciens NJN-6 volatile compounds against Fusarium oxysporum f. sp. cubense. Appl. Environ. Microbiol. 2012, 78, 5942-5944. [CrossRef]

75. Cheffi, M.; Bouket, A.C.; Alenezi, F.N.; Luptakova, L.; Belka, M.; Vallat, A.; Rateb, M.E.; Tounsi, S.; Triki, M.A.; Belbahri, L. Olea Europaea L. Root endophyte Bacillus velezensis OEE1 counteracts oomycete and fungal harmful pathogens and harbours a large repertoire of secreted and volatile metabolites and beneficial functional genes. Microorganisms 2019, 7, 314. [CrossRef] [PubMed]

76. Rathna, V. Exploiting the Bio Control Potentiality of Bacillus velezensis P42 and A6 Strains Against Important Bacterial Wilt and Early Blight Diseases of Tomato. Master's Thesis, University of Agricultural Sciences, GKVK, Bengaluru, India, 2018.

77. Nelson, B.A.; Ramaiya, P.; de Leon, A.L.; Kumar, R.; Crinklaw, A.; Jolkovsky, E.; Crane, J.M.; Bergstrom, G.C.; Rey, M.W. Complete genome sequence for the Fusarium head blight antagonist Bacillus amyloliquefaciens strain TrigoCor 1448. Genome Announc. 2014, 2, e00219-14. [CrossRef] 
78. Niazi, A.; Manzoor, S.; Asari, S.; Bejai, S.; Meijer, J.; Bongcam-Rudloff, E. Genome analysis of Bacillus amyloliquefaciens subsp. plantarum UCMB5113: A rhizobacterium that improves plant growth and stress management. PLoS ONE 2014, 9, e104651. [CrossRef] [PubMed]

79. Sun, Z.; Hsiang, T.; Zhou, Y.; Zhou, J. Draft genome sequence of Bacillus amyloliquefaciens XK-4-1, a plant growth-promoting endophyte with antifungal activity. Genome Announc. 2015, 3, e01306-15. [CrossRef] [PubMed]

80. Xu, S.; Xie, X.; Zhao, Y.; Shi, Y.; Chai, A.; Li, L.; Li, B. Whole-genome analysis of Bacillus velezensis ZF2, a biocontrol agent that protects Cucumis sativus against corynespora leaf spot diseases. 3 Biotech 2020, 10, 186. [CrossRef] [PubMed]

81. David Paul Raj, R.S.; Beena Kanimozhi, R.; Gomez, L.A.; Rohini, S. Evaluation of biocontrol efficacy of herbal and bioformulations against root rot pathogen Fusarium solani in tomato. Int. J. Recent Technol. Eng. 2019, 8, 5619-5625.

82. De Curtis, F.; Ianiri, G.; Raiola, A.; Ritieni, A.; Succi, M.; Tremonte, P.; Castoria, R. Integration of biological and chemical control of brown rot of stone fruits to reduce disease incidence on fruits and minimize fungicide residues in juice. Crop Prot. 2019, 119, 158-165. [CrossRef]

83. Pethybridge, S.J.; Gugino, B.K.; Kikkert, J.R. Efficacy of Double Nickel LC (Bacillus amyloliquefaciens D747 Strain) for management of white mold in snap and dry bean. Plant Health Prog. 2019, 20, 61-66. [CrossRef]

84. Burkett-Cadena, M.; Kokalis-Burelle, N.; Lawrence, K.S.; Van Santen, E.; Kloepper, J.W. Suppressiveness of root-knot nematodes mediated by rhizobacteria. Biol. Control 2008, 47, 55-59. [CrossRef]

85. Chen, X.H.; Koumoutsi, A.; Scholz, R.; Eisenreich, A.; Schneider, K.; Heinemeyer, I.; Morgenstern, B.; Voss, B.; Hess, W.R.; Reva, O; et al. Comparative analysis of the complete genome sequence of the plant growth-promoting bacterium Bacillus amyloliquefaciens FZB42. Nat. Biotechnol. 2007, 25, 1007-1014. [CrossRef] [PubMed]

86. Liu, X.Y.; Min, Y.; Wang, K.M.; Wan, Z.Y.; Zhang, Z.G.; Cao, C.X.; Zhou, R.H.; Jiang, A.B.; Liu, C.J.; Zhang, G.Y.; et al. Draft genome sequence of Bacillus amyloliquefaciens HB-26. Stand. Genomic Sci. 2014, 9, 775-782. [CrossRef] [PubMed]

87. Devaraj, K.; Aathika, S.; Periyasamy, K.; Periyaraman, P.M.; Palaniyandi, S.; Subramanian, S. Production of thermostable multiple enzymes from Bacillus amyloliquefaciens KUB29. Nat. Prod. Res. 2019, 33, 1674-1677. [CrossRef]

88. Kalawong, R.; Wakayama, M.; Anuntalabhochai, S.; Wongsawad, C.; Sangwijit, K. Comparison and characterization of purified cellulase and xylanase from Bacillus amyloliquefaciens CX1 and Bacillus subtilis B4. Chiang Mai J. Sci. 2018, 45, 92-105.

89. Farhat-Khemakhem, A.; Blibech, M.; Boukhris, I.; Makni, M.; Chouayekh, H. Assessment of the potential of the multi-enzyme producer Bacillus amyloliquefaciens US573 as alternative feed additive. J. Sci. Food Agric. 2018, 98, 1208-1215. [CrossRef]

90. Sewalt, V.; Shanahan, D.; Gregg, L.; La Marta, J.; Carrillo, R. The Generally Recognized as Safe (GRAS) process for industrial microbial enzymes. Ind. Biotechnol. 2016, 12, 295-302. [CrossRef]

91. Prajapati, V.S.; Ray, S.; Narayan, J.; Joshi, C.C.; Patel, K.C.; Trivedi, U.B.; Patel, R.M. Draft genome sequence of a thermostable, alkaliphilic $\alpha$-amylase and protease producing Bacillus amyloliquefaciens strain KCP2. 3 Biotech 2017, 7, 372. [CrossRef]

92. Meier, M.J.; Dodge, A.; Beaudette, L.A. Draft genome sequence of the industrially significant bacterium Bacillus amyloliquefaciens NRRL 942 Matthew. Microbiol. Resour. Announc. 2018, 7, e01374-18.

93. Montor-Antonio, J.J.; Sachman-Ruiz, B.; Lozano, L.; del Moral, S. Draft genome sequence of Bacillus amyloliquefaciens JJC33M, isolated from sugarcane soils in the papaloapan region, Mexico. Genome Announc. 2015, 3, e01519-14. [CrossRef] [PubMed]

94. Chen, L.; Gu, W.; Xu, H.-Y.; Yang, G.L.; Shan, X.F.; Chen, G.; Wang, C.F.; Qian, A.D. Complete genome sequence of Bacillus velezensis 157 isolated from Eucommia ulmoides with pathogenic bacteria inhibiting and lignocellulolytic enzymes production by SSF. 3 Biotech 2018, 8, 114. [CrossRef] [PubMed]

95. Gong, G.; Kim, S.; Lee, S.M.; Woo, H.M.; Park, T.H.; Um, Y. Complete genome sequence of Bacillus sp. 275, producing extracellular cellulolytic, xylanolytic and ligninolytic enzymes. J. Biotechnol. 2017, 254, 59-62. [CrossRef]

96. Hassan, M. The Role of Pectin Utilization in Root Colonization and Plant Growth-Promotion by Bacillus amyloliquefaciens subsp. plantarum (Bap). Master's Thesis, Auburn University, Auburn, ME, USA, 2016.

97. Das, R.; Liang, Z.; Li, G.; Mai, B.; An, T. Genome sequence of a spore-laccase forming, BPA-degrading Bacillus sp. GZB isolated from an electronic-waste recycling site reveals insights into BPA degradation pathways. Arch. Microbiol. 2019, 201, 623-638. [CrossRef] [PubMed]

98. Jung, J.Y.; Chun, B.H.; Moon, J.Y.; Yeo, S.H.; Jeon, C.O. Complete genome sequence of Bacillus methylotrophicus JJ-D34 isolated from deonjang, a korean traditional fermented soybean paste. J. Biotechnol. 2016, 219, 36-37. [CrossRef] [PubMed]

99. Yang, H.; Yang, L.; Li, X.; Li, H.; Tu, Z.; Wang, X. Genome sequencing, purification, and biochemical characterization of a strongly fibrinolytic enzyme from Bacillus amyloliquefaciens Jxnuwx-1 isolated from chinese traditional douchi. J. Gen. Appl. Microbiol. 2019. in Press. [CrossRef] [PubMed]

100. Marasini, D.; Cornell, C.R.; Oyewole, O.; Sheaff, R.J.; Fakhr, M.K. The whole-genome sequence of Bacillus velezensis strain SB1216 isolated from the great salt plains of Oklahoma reveals the presence of a novel extracellular RNase with antitumor activity. Genome Announc. 2017, 5, e01343-17. [CrossRef]

101. Song, P.; Xu, X.; Jiang, L.; Zhang, R.; Wang, J.; Xu, Q.; Li, S. Genome sequence of Bacillus subtilis SPZ1, an evolved strain for higher uptake rate of tributyrin. Genome Announc. 2013, 1, e00511-13. [CrossRef]

102. Zhai, L.; Ren, R.; Meng, D.; Tian, Q.; Guan, Z.; Cai, Y.; Liao, X. Comparison of aminotransferases of three Bacillus strains Bacillus altitudinis W3, Bacillus velezensis SYBC H47, and Bacillus amyloliquefaciens YP6 via genome analysis and bioinformatics. J. Appl. Genet. 2019, 60, 427-430. [CrossRef] 
103. Wu, L.; Li, X.; Ma, L.; Blom, J.; Wu, H.; Gu, Q.; Borriss, R.; Gao, X. The "pseudo-pathogenic" effect of plant growth-promoting bacilli on starchy plant storage organs is due to their $\alpha$-amylase activity which is stimulating endogenous opportunistic pathogens. Appl. Microbiol. Biotechnol. 2020, 104, 2701-2714. [CrossRef]

104. Clatworthy, A.E.; Pierson, E.; Hung, D.T. Targeting virulence: A new paradigm for antimicrobial therapy. Nat. Chem. Biol. 2007, 3, 541-548. [CrossRef]

105. Fazle Rabbee, M.; Baek, K.H. Antimicrobial activities of lipopeptides and polyketides of Bacillus velezensis for agricultural applications. Molecules 2020, 25, 4973. [CrossRef]

106. Perlman, D.; Bodanszey, M. Biosynthesis of peptide antibiotics. Annu. Rev. Microbiol. 1971, 40, 449-464. [CrossRef]

107. Hancock, R.E.; Chapple, D.S. Peptide antibiotics. Antimicrob. Agents Chemother. 1999, 43, 1317-1323. [CrossRef] [PubMed]

108. Grady, E.N.; MacDonald, J.; Ho, M.T.; Weselowski, B.; McDowell, T.; Solomon, O.; Renaud, J.; Yuan, Z.C. Characterization and complete genome analysis of the surfactin-producing, plant-protecting bacterium Bacillus velezensis 9D-6. BMC Microbiol. 2019, 19, 5. [CrossRef] [PubMed]

109. Xu, B.H.; Lu, Y.Q.; Ye, Z.W.; Zheng, Q.W.; Wei, T.; Lin, J.F.; Guo, L.Q. Genomics-guided discovery and structure identification of cyclic lipopeptides from the Bacillus siamensis JFL15. PLoS ONE 2018, 13, e0202893. [CrossRef]

110. Abdelhamid, A.G.; Hussein, W.E.; Gerst, M.M.; Yousef, A.E. Draft genome sequence of Bacillus velezensis OSY-GA1, which encodes multiple antimicrobial metabolites and expresses antimicrobial activity against foodborne pathogens. Microbiol. Resour. Announc. 2019, 8, e01725-18. [CrossRef] [PubMed]

111. Huffman, J.; Gerber, R.; Du, L. Recent advancements in the biosynthetic mechanisms for polyketide-derived mycotoxins. Biopolymers 2010, 93, 764-776. [CrossRef] [PubMed]

112. Weissman, K.J. Introduction to polyketide biosynthesis. Methods Enzymol. 2009, 459, 3-16. [PubMed]

113. Gomes, E.S.; Schuch, V.; Lemos, E.G.D.M. Biotechnology of polyketides: New breath of life for the novel antibiotic genetic pathways discovery through metagenomics. Brazilian J. Microbiol. 2013, 44, 1007-1034. [CrossRef] [PubMed]

114. Lee, H.J.; Chun, B.H.; Jeon, H.H.; Kim, Y.B.; Lee, S.H. Complete genome sequence of Bacillus velezensis YJ11-1-4, a strain with broadspectrum antimicrobial activity, isolated from traditional korean fermented soybean paste. Genome Announc. 2017, 5, e01352-17. [CrossRef] [PubMed]

115. Zheng, C.J.; Lee, S.; Lee, C.H.; Kim, W.G. Macrolactins O-R, glycosylated 24-membered lactones from Bacillus sp. AH159-1. J. Nat. Prod. 2007, 70, 1632-1635. [CrossRef] [PubMed]

116. Kechagia, M.; Basoulis, D.; Konstantopoulou, S.; Dimitriadi, D.; Gyftopoulou, K.; Skarmoutsou, N.; Fakiri, E.M. Health benefits of probiotics: A review. ISRN Nutr. 2013, 2013, 7. [CrossRef] [PubMed]

117. Ryu, M.S.; Yang, H.J.; Jeong, S.J.; Seo, J.W.; Ha, G.; Jeong, S.Y.; Jeong, D.Y. Characteristic study and optimization of culture conditions for Bacillus amyloliquefaciens SRCM 100731 as probiotic resource for companion animal. Microbiol. Soc. Korea 2018, 54, 384-397.

118. Brown, S.; Dart, P. Testing Hay Treated with Mould-Inhibiting, Biocontrol Inoculum; Rural Industries Research and Development Corporation: Canberra, Australia, 2005.

119. Pereira, J.Q.; Ritter, A.C.; Cibulski, S.; Brandelli, A. Functional genome annotation depicts probiotic properties of Bacillus velezensis FTC01. Gene 2019, 713, 143971. [CrossRef] [PubMed]

120. Karlyshev, A.V.; Melnikov, V.G.; Chistyakov, V.A. Draft genome sequence of Bacillus amyloliquefaciens B-1895. Genome Announc. 2014, 2, e00633-14. [CrossRef]

121. Golovko, G.; Zipelt, L.; Karpenko, G.; Chistyakov, V.; Sazykina, M.; Kolenko, M. Method for Growth of Young AzovChernomorskaya Royal Fish in Ponds. RU Patent No. 2,376,755, 23 July 2008.

122. AlGburi, A.; Volski, A.; Cugini, C.; Walsh, E.M.; Chistyakov, V.A.; Mazanko, M.S.; Bren, A.B.; Dicks, L.M.T.; Chikindas, M.L. Safety properties and probiotic potential of Bacillus subtilis KATMIRA1933 and Bacillus amyloliquefaciens B-1895. Adv. Microbiol. 2016, 6, 432-452. [CrossRef]

123. Yi, Y.; Zhang, Z.; Zhao, F.; Liu, H.; Yu, L.; Zha, J.; Wang, G. Probiotic potential of Bacillus velezensis JW: Antimicrobial activity against fish pathogenic bacteria and immune enhancement effects on Carassius auratus. Fish Shellfish Immunol. 2018, 78, 322-330 [CrossRef]

124. Gao, X.Y.; Liu, Y.; Miao, L.L.; Li, E.W.; Sun, G.X.; Liu, Y.; Liu, Z.P. Characterization and mechanism of anti-Aeromonas salmonicida activity of a marine probiotic strain, Bacillus velezensis V4. Appl. Microbiol. Biotechnol. 2017, 101, 3759-3768. [CrossRef] [PubMed]

125. Llario, F.; Romano, L.A.; Rodilla, M.; Sebastiá-Frasquet, M.T.; Poersch, L.H. Application of Bacillus amyloliquefaciens as probiotic for Litopenaeus vannamei (Boone, 1931) cultivated in a biofloc system. Iran. J. Fish. Sci. 2020, 19, 904-920.

126. Lin, Y.S.; Saputra, F.; Chen, Y.C.; Hu, S.Y. Dietary administration of Bacillus amyloliquefaciens R8 reduces hepatic oxidative stress and enhances nutrient metabolism and immunity against Aeromonas hydrophila and Streptococcus agalactiae in zebrafish (Danio rerio). Fish Shellfish Immunol. 2019, 86, 410-419. [CrossRef]

127. Al-Deriny, S.H.; Dawood, M.A.; Abou Zaid, A.A.; Wael, F.; Paray, B.A.; Van Doan, H.; Mohamed, R.A. The synergistic effects of Spirulina platensis and Bacillus amyloliquefaciens on the growth performance, intestinal histomorphology, and immune response of Nile tilapia (Oreochromis niloticus). Aquacult. Repot. 2020, 17, 100390. [CrossRef]

128. Chauhan, A.; Singh, R. Probiotics in aquaculture: A promising emerging alternative approach. Symbiosis 2019, 77, 99-113. [CrossRef] 
129. Azrin, N.A.R.; Yuzine, E.; Ina-Salwany, M.Y.; Karim, M. The Efficacy of Potential Probiont Bacillus amyloliquefaciens Strain L11 in Protecting Artemia Nauplii and Blue Crab Juveniles against Vibrio harveyi Infection. J. Pure Appl. Microbiol. 2019, 13, 923-931.

130. Abatenh, E.; Gizaw, B.; Tsegaye, Z.; Wassie, M. The role of microorganisms in bioremediation-a review. Open J. Environ. Biol. 2017, 1, 38-46. [CrossRef]

131. Meng, D.; Zhai, L.X.; Tian, Q.P.; Guan, Z.B.; Cai, Y.J.; Liao, X.R. Complete genome sequence of Bacillus amyloliquefaciens YP6, a plant growth rhizobacterium efficiently degrading a wide range of organophosphorus pesticides. J. Integr. Agric. 2019, 18, 2668-2672. [CrossRef] 